Citation: Giuseppe Cantafio, Luana Parisi (2021) Micro-Wineries as drivers for local economic development and innovation in lagging areas. Wine Economics and Policy 10(1): 23-32. doi: 10.36253/wep-8194

Copyright: (c) 2021 Giuseppe Cantafio, Luana Parisi. This is an open access, peer-reviewed article published by Firenze University Press (http://www. fupress.com/wep) and distributed under the terms of the Creative Commons Attribution License, which permits unrestricted use, distribution, and reproduction in any medium, provided the original author and source are credited.

Data Availability Statement: All relevant data are within the paper and its Supporting Information files.

Competing Interests: The Author(s) declare(s) no conflict of interest.

\section{Micro-Wineries as drivers for local economic development and innovation in lagging areas}

\author{
Giuseppe Cantafio ${ }^{1, *}$, Luana Parisi ${ }^{2}$ \\ ${ }^{1}$ University of Sunderland in London, 197 Marsh Wall, London, E14 9SG, Great Britain. \\ E-mail:giuseppe.cantafio@sunderland.ac.uk \\ ${ }^{2}$ School of Architecture, Computing and Engineering (ACE), University of East London \\ 4-6 University way, London E162RD, Great Britain.E-mail: L.Parisi2@uel.ac.uk \\ ${ }^{\star}$ Corresponding author
}

\begin{abstract}
For a long time mainstream economics has neglected the non-economic side related to economic growth. Yet, today there is increasing awareness of the role that social capital can play in spurring Local Economic Development especially in underdeveloped, remote, or lagging contexts. Microwineries represent a good example of SMEs, being small realities serving the local markets and spaces that strengthen local communities. The European Mediterranean regions have commonly been connected with these sectors. This study aims at pushing the body of knowledge in the development of microwineries in the lagging-behind contexts of Southern Europe, particularly in Southern Italy. To support the discussion, the present study will adopt a deductive approach, by analysing the San Diego wine cluster taken as a case study, since its wine market recently boomed. Findings will highlight the microwineries symbiosis with the territory itself. Useful lessons will be drawn for encouraging policymakers in undertaking actions towards strengthening the potential of microwineries and building networks among them.
\end{abstract}

Keywords: microwineries, SMEs, innovation, economic growth, business.

\section{INTRODUCTION}

Microwineries can be defined referring to the official classification provided by the European Commission [12]. This framework can be used to define Small and Medium Enterprises (SMEs), identifying micro, small and medium-sized enterprises with two main indicators, namely the number of employees and total assets. Microwineries are those firms that count less than 9 employees and produce less than 2 million euros in total assets.

They are considered as a new specialized organizational form that is proliferating recently in the wine market and is smaller in size than the farm winery, in that they tend to produce about 2,000 cases per year compared to the 40,000 cases of farm wineries [52].

Being categorized as small and medium enterprises (SMEs), microwineries are of a crucial importance as they are responsible for a country's wealth, and they furnish employment, as emphasized in various reports and academic papers [15]. 
Several studies have analysed the multifaceted thematic related to wine in various areas: some have deepened the topic of resilience between micro and small wineries, investigating approaches for helping businesses to be more resilient $[24,29,10]$. Under a different perspective, other studies have analysed the innovative marketing behaviour of small and medium wine enterprises in Italy [8] and the influence of size on winery performances [47]. Some scholars have provided a study of the internationalisation procedures related to the wine industry in southern Italy $[43,38]$; other studies highlight the "tourism and marketing characteristics of family-owned wineries" [21].

Similarly to microwineries, microbreweries, considered as small businesses specialised on the production of distinctive styles of beer through their own process [2], are growing in numbers in recent years. Some studies have focused on the role that craft breweries play for the innovation processes [11].

A few studies have had the objective of analysing and perceiving microwineries as pockets of specialisation and innovation, places in which creating and sharing knowledge accumulated through a millennial-long process of improvement of the product and resilience of the whole wine-related business.

In particular, scholars explored the innovation pattern of micro and small operators in the wine industry, by means of the theory of innovation [10].

This study is grounded on the following hypothesis:

H1: Microwineries have a strong linkage with the territory and the society itself, and thanks to them innovation can be spurred to the agricultural sector.

This study aims at pushing the body of knowledge in the development of microwineries in Southern Italy and, more in general, in Southern Europe and Mediterranean countries, with the goal to regenerate the existent wineries and transform them in actual places of knowledge sharing, where innovation can be applied to the agricultural sector. Microwineries can be seen also as places where tourists have the possibility to live a real experience, in contact with the real local culture of the place they visit.

The present study can also be seen as a source of ideas and information that could be useful to familyowned businesses, micro and small-size wine-related firms, that compose about the 99 per cent of all firms in the European Union [13].

\section{INNOVATION}

For a long time, mainstream economics has neglected the non-economic side related to economic growth.
Yet, today, there is increasing awareness of the role that social capital can play in spurring the local economic development especially in underdeveloped, remote, or lagging contexts. The social capital encompasses different aspects, such as the network of relationships, allowing knowledge exchange and spurring innovation.

While before innovation was considered as a process of creative destruction [46], or a function or activity among entrepreneurs [53], more recently, innovation has been understood as the driving force of long-term competitiveness, growth, and employment [9]. It has been found a positive relation between employment and innovation in relation to small manufacturing firms [38].

Therefore, it is a process that takes to a result that is by definition new, in the sense that it is a thing or a way of making a thing that was not there [22].

Thus, today the main goal and input of most of the organizations and companies is to build interactions, strengthening the social capital as both an input and an output of the development process [47] and as a key component of social innovation [22].

Microwineries, being small realities serving especially the local market, represent a good way for studying craft-based economic activities of small and medium-size. It is thanks to them that the social capital thrives, since crafts and SMEs are entrusted with the long-term development of the local economy and are embedded into local societies. This is in line with the fact that the majority of Italian wineries are familyowned and family-operated businesses [20].

Microwineries can help to foster the networks of relationships and the sharing of knowledge between people, consequently thriving social capital and boosting innovation, which can act as engines of the Local Economic Development.

Under this point of view, the concept of microwineries can be associated to the one of Rural Innovation Centres, whereas "Rural innovation is defined as the introduction of something new (a novel change) to economic or social life in rural areas, which adds new economic or social value to rural life" [33].

Thus, this perspective can let us consider microwineries as co-working spaces as well, defined as membership-based workplaces where freelancers, remote workers, and other autonomous professionals work together in a shared, common setting [50].

Around the world several co-working spaces that are also craft breweries are sprouting [51]. Cobrew, a local community for people with a common vision about sharing, collaborating and creating, in Australia, is depicted as a local co-working spacecraft where people from all innovative disciplines have at their disposal the 
tools and the facility to cultivate and brew project and ideas about their own craft. Galvanize, in Fort Collins, Colorado is a place where entrepreneurs from Fort Collins collaborate in the heart of this historic city. This city was classified in 2013 as the second most entrepreneurial city in America by Catherine Clifford [7].

The Workbar, in Cambridge, MA, is another example of working space that provides free tastings, events, and recommendations for beer aficionados. Apart from this aspect, there is also the fact that this is a place where people go to work on shared projects in an attractive working environment, which in turn increases the workers' productivity.

Overall, it emerges that microwineries can constitute the pockets of entrepreneurship and sustainability where to innervate innovation in rural areas.

This can be carried out through different funding projects in Europe: the policy framework of the Smart Specialisation Strategies [18] can help creating new competitive advantages for enhancing the economic growth.

Another example of policies for rural innovation and growth of firms is "Innogrow", a funding project that is constituted by 9 partners from 8 different countries, bringing together managing bodies and regional entities shaping local and national policies, to share knowledge and best practices, and how to better implement policies that promote the adoption of innovation and spurring the growth of small businesses linked to the rural economy [28].

RuralGrowth is another project with the aim of improving the policies related to small rural enterprises linked to the industry of hospitality. To carry out this, the project supports the adoption of sustainable and technologically advanced solutions as a way of fostering SMEs competitiveness and can serve as a push for the sustainable development in the rural regions [29].

\section{SCOPE OF WORK}

The present study aims at pushing the body of knowledge in the development of microwineries in Southern Italy and, more in general, in Southern Europe and Mediterranean countries, which rank among the first global places in terms of production of wine.

At the same time, recent economic indicators have shown that Mediterranean regions, including the Southern Italian and Greek areas, Cyprus, Malta, Southern Spain, Portugal, represent the poorest European areas and have lower GDP levels, if compared with the other European regions.

In Europe, urban regions can be classified as economic hubs that provide relatively high levels of wealth creation, while several social and economic problems are enduring in rural areas [16].

If we have a look at Italy, there is a unique situation, like a dramatic economic division between Northern regions and Southern ones, the so-called "Mezzogiorno", that has economic and social characteristics very similar to the ones of other Mediterranean countries [4].

Looking at the economic indicators of CentreNorthern Italian regions, they have a GDP per capita of $€ 31,124$, comparable with Germany, where the GDP per capita is $€ 31,703$. Vice versa, the "Mezzogiorno" richness levels are closer to poorer countries like Greece. As an example, Southern Italy has a GDP per capita of $€ 18,000$, while Greece showed a GDP per capita of $€ 18,500$ [6].

Other particular striking facts are referring to the post economic crisis period 2009-2013, in which the "Mezzogiorno" lost 39,500 firms; almost 10,000 of them were belonging to the manufacturing sector. A similar situation has been observed in other Mediterranean areas, and still most of Mediterranean areas have not fully recovered from the period of recession experienced after the economic crisis [6].

The Southern part of Italy has been one of the more affected by the economic crisis, which lasted about 7 years and has widened the gap between North and South. The South, in fact, has grown at a rate of $13 \%$ between 2000 and 2013, registering a more structured desertification process of the economic system. Its stagnant economy contrasts with the ones of the other EU disadvantaged regions, with a GDP per capita downward of about a $80 \%$ compared to a decade ago [37].

Another serious problem to be faced in different Mediterranean areas is the demographic decline. This can be appreciated from the study done by the German Institute BBSR where it has been observed a negative demographic trend in Mediterranean areas like Southern Italy, Greece, Portugal, and part of Spain. Some of these areas showed an average annual population fall of 2 percent or more. From recent reports emerged that the area of Southern Italy Apennines faced a demographic decline from 2001 to 2011 [1].

The phenomenon of population decline can be explained by several factors, including the economic crisis of the last years, which caused a reduction of job opportunities, especially for younger people.

A factor that influences the demography is the crude birth rate that was 10 births per 1,000 inhabitants or lower across southern Italy, with a similar trend with Eastern Europe (Bulgaria, Croatia, Hungary, Poland and Romania), Southern Europe (Greece, Spain, Malta and Portugal). 
Mediterranean regions like Southern Italy have one of the lowest fertility rates among European NUTS 3 regions [14].

Another problem linked to Mediterranean cities is the lack of environmental awareness and environmental sustainability of Mediterranean areas. This problem can be traced also in Southern Italian regions as it has been indicated in a report published by Legambiente, which is an Italian environmentalist association. This report is called "Ecosistema urbano", translation of urban ecosystem, and it depicts the situation of Italian cities by studying the performances by means of indicators and numbers coming from analysis inside cities, like public transportation, mobility, air pollution, waste management, energy and others. In particular, most of the cities classified at the bottom of the ranking published in the report are Southern cities. More in depth, in the whole Italy there are 104 provinces, and fourteen southern Italian provinces in 2017 ranked among the last twenty positions of this report [32].

\section{OPPORTUNITIES IN SOUTHERN EUROPE LINKED TO MICROWINERIES}

Mediterranean areas, which are the target of this study, have been widely connected with wine production. Nevertheless, only lately, as regions come to tackle the effects of global rural reorganisation, wine and oenological tourism have been used for local development and economic regeneration strategies.

The production of wine in Mediterranean countries constitutes an important asset for the economy. Italy is the first country in the world for production of wine and other Mediterranean countries present significant levels of wine production as well. France and Spain, for instance, are respectively the second and third producer of wine in the world [55]. In Italy the sector is characterised by an important fragmentation and a strong dichotomy, with more than half of the firms growing less than 3 ha of grapes and with only $4 \%$ owning over 30ha. Therefore, on the one hand, the sector accounts a large number of small businesses, often being familyowned and managed and for self or local consumption, and, on the other hand, businesses of a medium and big size with significant levels of professionalism [47].

Local and self-consumption against high levels of vertical integration in the production process. This leads to an improved connection between micro wine players, which could potentially increase their added value.

As highlighted above in the section dedicated to innovation, in view of the positive link between employ- ment and innovation when it comes to micro sized manufacturing firms, this could also have a triple down effect on the employment numbers of large amount of young people attracted by the triggered innovation of this appealing sector. Demographically, it can be deducted that the above explained phenomenon of population decline in the Southern regions of Europe could be also narrowed.

The sector includes wine making and growing of grapes, but also wine-related tourism. In this regard, several studies have deepened the concept of wine tourism and its development in the last years. The concept of Themed Touring Routes (TTRs) refers to paths and road segments that connect proximate tourism attractions intended as nodal points of a network, under a principal topic or product. Many studies have characterised the concept of TTR [56] and analysed the role of wineries and vineyards collaborating to magnetise tourists and sponsor their products [52].

Microwineries can, indeed, become places where tourists can live a real experience, being in contact with the real local culture of the place they visit. This same concept could be applied to the Calabrian context, where wineries could contribute to the ecotourism and serve as a trigger for the Economic Development of Calabria [5].

As examined by several studies, TTRs, in turn, have positive effects on local economic development, particularly in rural areas [3].

\section{METHODOLOGY}

As stated in the introduction, microwineries can be considered as local clusters constituting pockets of specialisation where it is possible to innervate innovation. Since innovation and specialisation are the two parameters of competitiveness, this process helps to develop new competitive advantages for the territory, helpful to enhance the economic growth. As stated by Foray [19], regions need to "specialize themselves", developing strategic visions, locating investments where regional strengths indicate opportunities to move up in the international value chains. The strategy takes the activities with more potential out of the territory, through a vertical logic transforming them into domains of specialization for a certain length of time and bringing them into the broader Regional Innovation Strategy, that is more horizontal [47].

For supporting the discussion, the research design will be based on the case study [57]; this descriptive and exploratory approach has been implemented in order to adopt a grade of detailed analysis to define the relevance of themes treated in the present study. 


\section{RATIONALE FOR RESEARCH APPROACH}

Research approaches explain the factors on which the researchers can frame the steps of gathering data and examine different literatures from different school of thoughts. There are two main approaches of research in this sense, specifically the inductive approaches and deductive approaches. In the circumstance of inductive approach, the researcher relies on the process of data collection for setting up a new theory that can eventually lead them to construct the structure required to build up concepts and theories that may emerge from the research.

On one side there is the deductive approach, which leads a researcher to adopt initiatives for studying different concepts and literatures in the beginning [31]. This aids in originating ideas and then attempts to defend them with the help of data collection. From another point of view this suggests that if the practise of data collection follows the procedure of literature review then it can be said that it has adopted a deductive approach. The present study has followed the deductive approach.

The rationale adopted for the present study has been constructed by means of deductive approach then; this study has been able to classify the different theories that exist regarding the concept of innovation management in the microwineries sector.

The wine cluster of San Diego, California, become an important case study for understanding key characteristics and implications of a sector that is growing in parallel and complementarily with innovation spaces. According to the San Diego County Vintners Association [45], there are currently about "142 active and planned wineries in San Diego County. Local wineries are located throughout the region, and satellite tasting rooms reach many of the urban and coastal communities that dot the San Diego landscape." These include an abundance of microwineries that are occupying the innovation spaces in the city centre.

The next section will deepen meanings, implications and evidence of this phenomenon.

\section{RESULTS}

The San Diego wine cluster has been deepened as a case study, since its wine market recently boomed, challenging the historic worldwide producers and constituting an important slice of the local market.

As a matter of fact, in the recent years, California has emerged as one of the major players in the global wine industry [40], so that about $90 \%$ of wine from the United States is produced in this State [55].

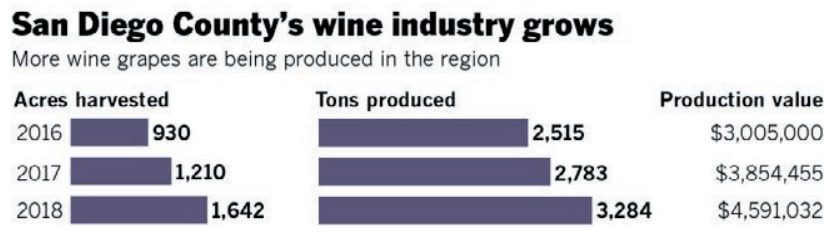

Figure 1. San Diego County Vintners Association [45].

Looking at the sectors composing its market, while the agricultural branch decreased by $9 \%$ between 2007 and 2012 and manufacturing jobs went down as well by $4 \%$ between 1998-2016, the wine market of the county of San Diego is now among the leading sectors of the local economy [54], registering \$30.4 million regional economic impact in 2016.

Moreover, from 2010 to 2017 the "total acres of wine grapes harvested" have grown by $111 \%$ [45] and, according to Professor Porter there has been a $+53 \%$ in terms of job creation between 1998 and 2015, a growth of $+68 \%$ in terms of establishments (1998-2015) and a $+8 \%$ increase in wages (2001-2015) [54].

In 2017, 116 are the "artisan and family-owned wineries and vineyards" that have been registered throughout the County [45]. In 2018, wineries generated $\$ 41.59$ million in gross sales, which is about $57 \%$ more compared to 2017 and about 72\% increase from 2016 sales [45].

Moreover, according to the scholar Showley, about $45 \%$ of 2016 rented office space went to coworking spaces [49] that include microbreweries and microwineries.

Overall, this growing phenomenon gives the picture of an environment that is socially and economically growing thanks to the links of the microbreweries and microwineries with the local innovation ecosystem in general, and with the other spaces of innovation located in the area. Microwineries can work as innovation spaces and are places where the two aspects of getting work done and experiencing a work/life balance merge together.

Figure 2 shows the co-working spaces and other innovation spaces present in the San Diego urban context as of 2018, it is possible to appreciate the high density of such spaces of innovation and knowledge sharing:

The Rural Innovation Centre (RIC) is an example of an existing place of knowledge sharing located in an urban context, and it was funded by the University and the Frank Parkinson Trust. This centre entails many activities such as teaching, mentoring and functions as a hub for events, with laboratory research workshop, a machinery workshop, a demonstration hall and has extensive external training capacity [44].

An existing example like the one of RIC can suggest how a knowledge and innovation centre in an urban 


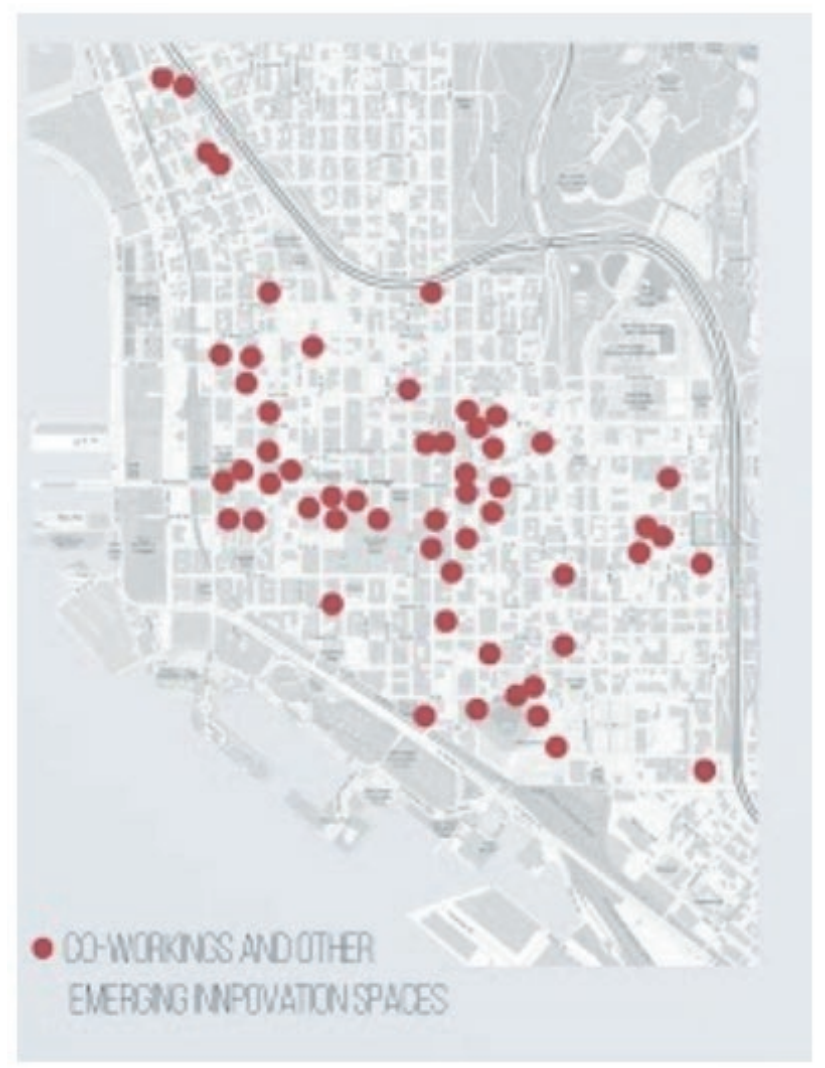

Figure 2. Map of San Diego Innovation centres (Authors' elaboration).

Table 1. Economic Dynamics of San Diego Wineries [45].

\begin{tabular}{|l|r|r|r|r|}
\hline Impact Type & Employment & \multicolumn{1}{|c|}{ Wages } & $\begin{array}{c}\text { Economic } \\
\text { Impact }\end{array}$ & \multicolumn{1}{|c|}{ Sales } \\
\hline Direct Effect & 611.7 & $\$ 27,384,200$ & $\$ 32,356,633$ & $\$ 41,059,126$ \\
\hline Indirect Effect & 149.55 & $\$ 6,777,197$ & $\$ 10,520,649$ & $\$ 17,768,378$ \\
\hline Induced Effect & 167.47 & $\$ 8,379,492$ & $\$ 15,738,777$ & $\$ 25,331,462$ \\
\hline Total Effect & 928.72 & $\$ 42,540,889$ & $\$ 58,616,060$ & $\$ 84,158,966$ \\
\hline
\end{tabular}

area with the support of anchor institutions (an academic institution and a charity) can have a key role in spurring individuals' capabilities and pushing local communities towards an entrepreneurial spirit for attaining business development, personal success and the growth of an entire community.

Moreover, it has the potential to create a direct, indirect and induced effect on the creation of new jobs in the region, as evidenced in Table 1:

\section{DISCUSSION}

The case studies provided emphasised an example that can give the guidelines for defining a new role of microwineries in southern Italy and Mediterranean areas. The process hypothesised could be seen as a shift in the way the industry works: a modernisation of the microwineries industry framework could in turn generate different spill-over effects that could change and improve the classical framework of the industry, as explained in previous studies. This can be displayed in the following infographics in figures 3 and 4 :

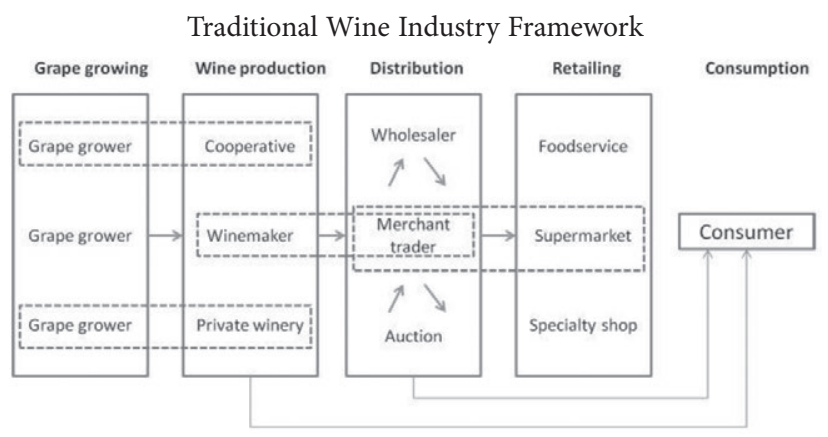

Figure 3. The Framework of Wine Value Chain [24].

In the following the proposed new Framework for microwineries conceived as Knowledge and Innovation Spaces and links with other actors of the innovation ecosystem:

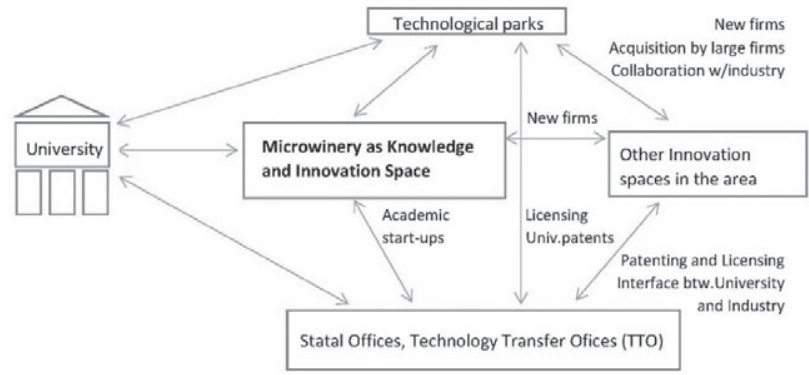

Figure 4. Framework of Knowledge Transfer and effect on an area's level of innovation (Authors' elaboration, adapted from Olcay \& Bulu [36]).

The effects of microwineries as innovation centres and co-working spaces could be many. One of them could be in the transformation of the rural areas in more knowledge-based areas, based on the theory of knowledge-based rural development, known as KBUD [58]. Microwineries could serve as Knowledge and Innovation spaces, where holding events, sharing knowledge on the industry and entrepreneurship, and places where 
transmitting to younger generation the passion and the secrets of crafting wines.

We can appreciate the differences between the two frameworks compared in fig.3-4, where in the former we have a classical approach, aimed at the consumption of the wine to the final consumer; in the latter we have a completely revolutionised approach, where the final aim is not the mere consumption of the produce, but the knowledge sharing and the connected spill-over effects such as the creation of new firms and improved connections with anchor institutions such as the university, the enlargement of the entrepreneurial community of the area, and the major collaboration with public stakeholder as state offices and technological transfer offices (TTOs).

In the present study the development approach is applied to rural areas, therefore it assumes the terms of knowledge-based rural development (KBRD), with the aim of spurring the economy of small villages and urban areas of European rural peripheral regions, seeking prosperity, environmental sustainability, and more social cohesion, as some of the results of the action of microwineries as rural innovation centres.

\section{CONCLUSIONS, LIMITATIONS AND FUTURE RESEARCH}

Findings from the research highlighted the microwineries symbiosis with the territory and the society itself, therefore meeting the hypothesis (H1) formulated by the researchers. Microwineries are able to strengthen the urban-rural link, revitalizing rural realities that are commonly considered out of the touristic channels as well. Indeed, they can offer to tourists' unique experiences in contact with local cultures, proposing tours, courses and workshops. Thus, positive relations between them and the broad regional innovation strategy emerge as well, showing the snowball effect on the levels of social capital and Local Economic Development in lagging contexts. Useful lessons are drawn for encouraging policy makers and planners in undertaking actions towards strengthening the potential of microwineries and building a network of relations among them.

Finally, comparative, benchmarking studies, addressing the lessons learned from the incorporation of new innovation centres inside microwineries also imply considerations regarding policy framing in the southern Europe and in Mediterranean areas. Addressing the lessons learned would also be of significance in generating greater understanding of the issues in this area [42].

Therefore, this paper advocates a significant change in the way that microwineries in lagging-behind con- texts, like the ones of Southern Europe, are managed.

Since microwineries can act as co-working spaces, strengthening local communities, it is necessary to consider them as spots of knowledge-sharing.

Thus, in essence, they can be considered as pockets of specialization where to innervate innovation by means of the Smart Specialization Strategies, creating new competitive advantages for enhancing the economic growth in lagging behind contexts.

The ideas drawn from the paper try to push towards a regeneration of the existing realities, creating spots of knowledge-sharing where also tourists can live experiences in contact with local cultures. This matter encompasses sustainable tourism development, innovation, and wider domains of social and economic policy, which are hypothesized in the present work. The approach is to recognize the importance of innovation, and advocating towards a cultural shift that would lead to the regeneration of existing structures and small businesses, but also to the evolution of social innovation within policy and planning. These issues can be considered only if a holistic approach will be embraced, which comprehends the inter-dependencies of urban planning with other political, social, economic and cultural issues. These, in turn, can be perceived as key drivers for the creation of economic stability and the spur of local innovation and knowledge sharing, making the notion of achieving an improved culture sharing and a realistic proposition for improved local economic development, innovation, and tourism reinforcement.

The research does come with its limitations. First, conclusions generalise from the San Diego case study and this should be done with caution. Second, primary data referring to microwineries in Southern Italy, including interviews and surveys should have been conducted to support the results.

Future lines of research should address these limitations, identifying a sample of microwineries in Southern Italy and Mediterranean areas to include the variables and evidence that are not considered in this study.

\section{REFERENCES}

[1] BBSR (2016). BBSR Homepage - Spatial development in Europe - Where the population in Europe is growing or shrinking. [online] Bbsr.bund.de. Available at: https://www.bbsr.bund.de/BBSR/EN/ SpatialDevelopment/SpatialDevelopmentEurope/ AnalysesSpatialDevelopment/Projects/PopulationDevelopment/population-development.html [Accessed 30 May 2018]. 
[2] Bastian, C.T., Oakley-Simpson, D.M., McLeod, D.M., Menklaus, D.J., Alsup, D., Ogden, J. and Whipple, G.D. (1999), "Niche market potential: the case of the US craft brewing industry", Review of Agricultural Economics, Vol. 21 No. 2, pp. 552-562.

[3] Briedenhann, J., \& Wickens, E. (2004). Tourism routes as a tool for the economic development of rural areas: Vibrant hope or impossible dream? Tourism Management, 25(1), 71-79.

[4] Cantafio, G.U. (2017). "Merging Economic Development with Clusters Theory and Environmental Sustainability" (unpublished $\mathrm{PhD}$ thesis), Reggio Calabria, Università degli Studi di Reggio Calabria Mediterranea.

[5] Cantafio, G.U. and Nadda, V., (2020). Ecotourism as a Trigger for Economic Development: A ResourceBased View of Calabria. In Handbook of Research on the Role of Tourism in Achieving Sustainable Development Goals (pp. 138-150). IGI Global.

[6] Censis. (2013). Rapporto sulla situazione sociale del paese. Angeli.

[7] Clifford, C. (2013). The 25 Best U.S. Cities For Tech Startups. [online] Entrepreneur. Available at: $<$ https://www.entrepreneur.com/article/227829> [Accessed 7 July 2020].

[8] Contò, F., Fiore, M., Vrontis, D., \& Silvestri, R. (2015). Innovative marketing behaviour determinants in wine SMEs: The case of an Italian wine region. International Journal of Globalisation and Small Business, 7(2), 107-124

[9] Das, S., \& Finne, H. (2008). Innovation and colocation. Spatial Economic Analysis, 3(2), 159-194.

[10] Duarte Alonso, A., \& Bressan, A. (2015). Resilience in the context of Italian micro and small wineries: an empirical study. International Journal of Wine Business Research, 27(1), 40-60.

[11] Duarte Alonso, A., Bressan, A., \& Sakellarios, N. (2017). Exploring innovation perceptions and practices among micro and small craft breweries: A three-country study. International Journal of Wine Business Research, 29(2), 140-158.

[12] European Union Commission. (2003). Commission recommendation of 6 May 2003 concerning the definition of micro, small and medium-sized enterprises. Official Journal of the European Union, 46, 36-41.

[13] European Commission (2013), "Fact and figures about the EU's small and medium enterprise (SME)", available at: http://ec.europa.eu/enterprise/ policies/sme/facts-figures-analysis/index_en.htm

[14] European Commission (2015a). Demography report. [online] Available at: http://ec.europa.eu/
eurostat/documents/3217494/6917833/KE-BM15-003-EN-N.pdf/76dac490-9176-47bc-80d9029e1d967af6 [Accessed 25 May 2018].

[15] European Commission (2015b), "Supporting entrepreneurs and self-employed - Microfinance", available at: http://ec.europa.eu/social $/$ main.jsp?catId=9 52\&intPageId=3510\&langId=en

[16] European Union (2016). Urban Europe Statistics on cities, towns and suburbs. Statistical Book, Eurostat. [ebook] Luxembourg: Publications office of the European Union. Available at: http://ec.europa.eu/eurostat/documents/3217494/7596823/KS-01-16-691-EN-N. pdf/0abf140c-ccc7-4a7f-b236-682effcde10f [Accessed 30 May 2018].

[17] Eurostat. (2018). Unemployment by sex and age annual average. [online] Available at: http://appsso. eurostat.ec.europa.eu/nui/submitViewTableAction. do [Accessed 31 May 2018].

[18] Foray, D., David, P. and Hall, B. (2011): Smart Specialisation: From academic idea to political instrument, the surprising career of a concept and the difficulties involved in its implementation, MTEI Working Paper 2011-001, EPFL, Lausanne.

[19] Foray, D. (2015) Smart Specialisation: Challenges and Opportunities for Regional Innovation Policies, Routledge.

[20] Gallucci, C. and D'Amato, A., (2013). Exploring nonlinear effects of family power on the performance of Italian wine businesses. International Journal of Wine Business Research.

[21] García, F., Meraz, R., \& Díaz, G. (2018). Wine tourism and wine marketing in family-owned micro wineries in Guadalupe Valley, Mexico. Rosa dos Ventos, 10(4), 690-711.

[22] Gedajlovic, E., Honig, B., Moore, C.B., Payne, G.T. and Wright, M., 2013. Social capital and entrepreneurship: A schema and research agenda. Entrepreneurship Theory and Practice, 37(3), pp.455-478.

[23] Godin, B. (2008). Innovation: the History of a Category. Project on the Intellectual History of Innovation Working Paper, 1.

[24] Goncharuk, A.G. (2017). The Challenges of Wine Business in Research. Journal of Applied Management and Investments, 6(4), pp.253-259.

[25] Gunasekaran, A. , Rai, B.K. and Griffin, M. (2011), "Resilience and competitiveness of small and medium size enterprises: an empirical research", International Journal of Production Research, Vol. 49 No. 18 , pp. $5489-55$

[26] Hall, C. M., \& Mitchell, R. (2000). Wine tourism in the Mediterranean: A tool for restructuring and 
development. Thunderbird International Business Review, 42(4), 445-465.

[27] Hausmann, R., Rodrik, D., 2003. Economic development as self-discovery. Journal of Development Economics 72, 603-633.

[28] Interreg Europe. (2019a). INNOGROW. [online] Available at: https://www.interregeurope.eu/innogrow/ [Accessed 18 Jan. 2019].

[29] Interreg Europe. (2019b). RuralGrowth. [online] Available at: https://www.interregeurope.eu/ruralgrowth/ [Accessed 18 Jan. 2019].

[30] Ismail, H.S., Poolton, J. and Sharifi, H. (2011). “The role of agile strategic capabilities in achieving resilience in manufacturing-based small companies", International Journal of Production Research, Vol. 49 No. 18, pp. 5469-5487

[31] Kumar, R., (2019). Research methodology: A stepby-step guide for beginners. Sage Publications Limited.

[32] Legambiente (2017). ECOSISTEMA URBANO XXII Rapporto sulla qualità ambientale dei comuni capoluogo di provincia. [online] Available at: https://www.legambiente.it/sites/default/files/docs/ ecosistema_urbano_2017_dossier.pdf [Accessed 31 May 2018].

[33] Mahroum, S., Atterton, J., Ward, N., Williams, A., Naylor, R., Hindle, R. and Rowe, F. (2019). Rural Innovation. 1st ed. [ebook] Nesta, p.6. Available at: https://media.nesta.org.uk/documents/rural_innovation.pdf [Accessed 18 Jan. 2019].

[34] Metcalfe, J.S. (1998) Evolutionary Economics and Creative Destruction. London and New York: Routledge.

[35] OECD (2016), OECD Regions at a Glance 2016, OECD Publishing, Paris. Available at: http://dx.doi. org/10.1787/reg_glance- 2016-en.

[36] Olcay, J.A. \& Bulu, M. (2016) Technoparks and Technology Transfer Offices as Drivers of an Innovation Economy: Lessons from Istanbul's Innovation Spaces, Journal of Urban Technology, 23:1, 71-93, DOI: 10.1080/10630732.2015.1090195

[37] Parisi, L. (2017). "Creative and Cultural Industries within Port Environments: a Smart Specialisation Strategy for Southern Italy" (unpublished $\mathrm{PhD}$ thesis), Reggio Calabria, Università degli Studi di Reggio Calabria Mediterranea.

[38] Pellicanò, A., \& De Luca, A. I. (2016). Dynamics, motivations and barriers in internationalisation processes of wineries in Calabria. Journal of wine research, 27(4), 257-283.

[39] Piva, M., \& Vivarelli, M. (2005). Innovation and employment: Evidence from Italian microdata. Journal of Economics, 86(1), 65-83.
[40] Porter, M. E., \& Bond, G. C. (2004). The California wine cluster. Boston, MA: Harvard Business School.

[41] Plummer, R., Telfer, D., Hashimoto, A., \& Summers, R. (2005). Beer tourism in Canada along the Waterloo-Wellington Ale Trail. Tourism Management, 26(3), 447-458.

[42] Rose, R. (1991). What is lesson-drawing? Glasgow: Centre for the Study of Public Policy.

[43] Rossi, M., Vrontis, D. and Thrassou, A. (2012), Wine business in a changing competitive environment - strategic and financial choices of Campania wine firms, International Journal of Business and Globalization, Vol. 8 No. 1, pp. 112-130.

[44] Royal Agricultural University. (2019). Rural Innovation Centre. [online] Available at: https://www. rau.ac.uk/about/farms/rural-innovation-centre [Accessed 16 Jan. 2019].

[45] San Diego County Vintners Association (2019), 2019 San Diego County Economic Impact of Wineries. Available at: https://sandiegowineries.org/wpcontent/uploads/2019/11/2019-San-Diego-CountyEconomic-Impact-of-Wineries-Report_Final.pdf [Accessed 13 Nov. 2020].

[46] Schumpeter, J. (1942). Creative destruction. Capitalism, socialism and democracy, 82-5.

[47] Sellers, R., \& Alampi-Sottini, V. (2016). The influence of size on winery performance: Evidence from Italy. Wine Economics and Policy, 5(1), 33-41.

[48] Serageldin, I. and Grootaert, C., 1998. 10. Defining social capital: an integrating view. Evaluation and Development: the institutional dimension, 1, p.203.

[49] Showley, R., 2017. Gensler: Redesigning San Diego, from North to South, The San Diego Union-Tribune.

[50] Spreitzer, G., Bacevice, P., \& Garrett, L. (2015). Why People Thrive in Coworking Spaces. Harvard Business Review, 93(7), 28-30.

[51] Stone, Z. (2013). Inside The World's First "Brewery Incubator". Available at: https://www.fastcompany. com/1681215/inside-the-worlds-first-brewery-incubator [Accessed 25 Jan. 2019].

[52] Swaminathan, A., (1995). The proliferation of specialist organizations in the American wine industry, 1941-1990. Administrative Science Quarterly, pp.653-680.

[53] Sweezy, P. M. (1943). Professor Schumpeter's theory of innovation. The review of economic statistics, 93-96.

[54] U.S. Cluster Mapping (2019). Available at: http:// www.clustermapping.us (Accessed: 17 February 2019). 
[55] Wine Institute (2016), "World wine production by country: 2013-2015 and \% change 2015/2013", available at: http://www.wineinstitute.org/files/ World_Wine_Production_by_Country_2015.pdf

[56] Xu, S., Leung, Y. F., \& Barbieri, C. (2016). Characterizing themed touring routes: a geospatial and tourism evaluation of wine trails. Tourism Planning \& Development, 13(2), 168-184.

[57] Yin, R. K. (2009). Case study research: Design and method (4th ed.). Sage: London.

[58] Yigitcanlar, S. \& Bulu, M. (2016) Urban Knowledge and Innovation Spaces, Journal of Urban Technology, 23:1,1-9, DOI: 10.1080/10630732.2016.1164443 